\title{
Changes in diet and maternal attendance of South American sea lions indicate changes in the marine environment and prey abundance
}

\author{
Karim H. Soto ${ }^{1,2, *}$, Andrew W. Trites ${ }^{1}$, M. Arias-Schreiber ${ }^{2}$ \\ ${ }^{1}$ Marine Mammal Research Unit, University of British Columbia, Room 247, AERL, 2202 Main Mall, Vancouver, \\ British Columbia V6T 1Z4, Canada \\ ${ }^{2}$ Instituto del Mar del Peru (IMARPE), Esquina Gamarra y General Valle S/N Chucuito-Callao, Peru
}

\begin{abstract}
Behavioural observations were made of South American sea lions Otaria flavescens in Peru to determine whether changes in their diet and maternal attendance patterns reflected physical changes in the marine environment and alterations in the abundance and distribution of prey. The study was conducted during the breeding season between 1998 and 2002, which was a period that encompassed a strong El Niño (1997 to 1998) and a moderate La Niña (1999 to 2001). Observations revealed strong linkages between maternal attendance patterns and the abundance of prey and oceanographic features close to the rookeries. Acute prey shortage during El Niño resulted in females increasing the length of their foraging trips and decreasing the time they spent onshore with their pups. In contrast, shorter times at sea and longer times onshore were observed during the favourable conditions of La Niña when preferred prey (anchovy and squat lobster) were more abundant near the rookeries. Pup mortalities increased when females spent more time at sea searching for prey and did not return frequently enough to nurse their pups. A larger diversity of prey species (particularly of demersal fishes) was consumed during El Niño when anchovy and lobster were less available. Females appeared to adjust their diets and maternal attendance patterns in response to annual changes in the abundance and distribution of prey. These observations suggested that diet and maternal responses reflect interannual fluctuations of the unpredictable Peruvian upwelling ecosystem, and implied that South American sea lions may be good indicators of relative changes in the distribution and abundance of marine resources.
\end{abstract}

KEY WORDS: South American sea lion - Otaria flavescens · Environmental change · Maternal attendance $\cdot$ Diet $\cdot$ El Niño $\cdot$ La Niña $\cdot$ Prey abundance

Resale or republication not permitted without written consent of the publisher

\section{INTRODUCTION}

In theory, fluctuations in oceanography and changes in ocean productivity directly affect the abundance and distribution of prey species, which in turn affect the reproductive and foraging ecology of their predators (McCann 1987, Trillmich \& Ono 1991, Guinet et al. 2001). A number of studies have related changes in the foraging behaviour of apex predators such as pinnipeds, whales, and sea birds to the abundance of the prey that they feed upon (e.g. Boyd et al. 1994, 2002, Boyd 1999). However, the degree to which behavioural responses of apex predators are proxies for changes in the marine environ- ment is still not clear. Due to the difficulty and costs of conducting such research, only a few studies have attempted to validate the relationship between prey and foraging behaviour by assessing oceanographic conditions or the distribution and abundance of prey (e.g. Boyd \& Arnbom 1991, Lea \& Dubroca 2003). A better understanding of this relationship would help guide the use of apex predators as indicators of marine environmental change. It might also help to assess the consequences of fishing on the foraging ecology of apex predators and potential competition with humans for marine resources.

Female South American sea lions Otaria flavescens in Peru offer an opportunity to evaluate the strength of 
the relationship between fluctuations in the marine ecosystem and the reproductive ecology of apex predators. South American sea lions inhabit the productive but unpredictable Peruvian upwelling ecosystem (Ryther 1969), and are directly exposed to interannual and highly stochastic fluctuations in the distribution and abundance of their principal preythe Peruvian anchovy Engraulis ringens (AriasSchreiber 2003). The distribution and abundance of anchovy, as well as the negative effects of El Niño events on its life history, have been well documented due to the economic importance of anchovy to the Peruvian fishing industry (Barber \& Chavez 1986, Pauly \& Tsukayama 1987, Niquen \& Bouchon 2002). Similarly, considerable knowledge has been gathered on the foraging behaviour, reproduction, and diet of South American sea lions throughout their distributional range along the Atlantic and Pacific coasts of South America (Campagna \& Le Boeuf 1988a, Thompson et al. 1998, Soto 1999, Koen Alonso et al. 2000, Campagna et al. 2001, Soto et al. 2004). Females are easy to monitor because they give birth on land and alternate intermittent trips at sea to feed (foraging trips) with visits onshore to nurse their pups during the austral summer (Campagna \& Le Boeuf 1988a). Female sea lions also provide all the nutritional resources needed to rear their pups, and do not rely on fat reserves stored before parturition (Trillmich et al. 1991). Thus, stochastic fluctuations in the marine environment should directly affect the maternal behaviour and possibly also the reproductive success of this species.

The goal of our study was to determine whether behavioural measurements of apex predators reflected physical changes in the marine environment and fluctuations in the abundance and distribution of prey. South American sea lion diets and behavioural observations of maternal attendance patterns were assessed at the Ballestas Islands, Peru, over 5 consecutive breeding seasons of contrasting prey abundance that included the strongest El Niño on record (from 1997 to 1998) (McPhaden 1999) and a moderate La Niña (from 1999 to 2001). We investigated the reproductive ecology of sea lions (maternal attendance and dietary habits) and its relationship with oceanographic variables (sea temperature anomalies) and marine prey resources (distribution and abundance of anchovy) at corresponding spatial and temporal scales.

\section{MATERIALS AND METHODS}

Study site. Data were collected from the Ballestas Islands $\left(13^{\circ} 44^{\prime} \mathrm{S}, 76^{\circ} 24^{\prime} \mathrm{W}\right)$, Pisco, which are home to one of the largest breeding concentrations of South
American sea lions in Peru (Arias-Schreiber \& Rivas 1998). The islands are protected by the Peruvian Government as a guano bird reserve. The main study area, La Maternidad ('The Maternity'), is an open pebble beach without pools or shaded areas that allows for all sea lions using the rookery to be observed. It is bounded to the north by open ocean, to the south by a rocky cliff, and to the east and west by small caves.

Diet. Diet was determined from scats collected by the Instituto del Mar del Peru (IMARPE) at San Gallan Island $\left(13^{\circ} 51^{\prime} \mathrm{S}, 76^{\circ} 26^{\prime} \mathrm{W}\right)$, Pisco, a nearby breeding rookery that was approximately $7 \mathrm{~km}$ from our study site. The topography of our behavioural study site at La Maternidad prevented access to the beach to collect scats. The number of scats collected from San Gallan Island varied among years (January and March 1998: n = 139; January and March 1999: $\mathrm{n}=81$; April 2000: $\mathrm{n}=50$; January 2001: $\mathrm{n}=21$; January and February 2002: $\mathrm{n}=84$ ). Hard parts identifiable to species level were recovered from all scats with the exception of those that contained no identifiable hard parts; these amounted to 60 scats collected in 1998 (El Niño), 8 in 1999 (La Niña), and 10 in 2002.

Scats were frozen after collection, then later thawed and washed using a series of nested sieves with mesh sizes of 2.0, 0.425 and $0.25 \mathrm{~mm}$ (USA Standard Test). Fish otoliths, cephalopod beaks, and crustacean remains were separated. Otoliths were identified to species level where possible using reference collections of IMARPE and the identification guide of García-Godos (2001). Cephalopod beaks were not identified to species level, and crustacean remains did not accurately reflect the number of individuals in each sample due to advanced stages of digestion. Thus, only the frequency of occurrence (defined as the number of scats in which a given prey occurred) (Dellinger \& Trillmich 1988) of each taxonomic group was included in the analysis.

Maternal attendance. South American sea lions normally breed during the austral summer (between December and March). However, the timing and duration of the breeding seasons varies according to latitude (Campagna 1985, Soto 1999) and interannual fluctuations in prey abundance (Soto et al. 2004). Observations at the Ballestas Islands were made during 5 consecutive breeding seasons (between 4 January and 10 March) from 1998 to 2002, and also between November and December 1997. Maternal attendance was defined as the duration of individual female attendance cycles (i.e. time spent at sea foraging and time spent onshore nursing their pups). Since the timing of births varied among years (see Soto et al. 2004), females were marked around the peak of each pupping season to standardize for possible developmental differences that might affect interannual comparisons. Females were marked with paint pellets fired from a $\mathrm{CO}_{2}$ gun (Nel-Spot Company), and with paint-filled eggs thrown up to $35 \mathrm{~m}$ 
from the animals. Females were marked on their day of parturition or during the perinatal period, i.e. the interval between parturition and a mother's first departure to sea $(1998: \mathrm{n}=42 ; 1999: \mathrm{n}=124 ; 2000: \mathrm{n}=155 ; 2001$ : $\mathrm{n}=124 ; 2002: \mathrm{n}=110$ ). The small sample size during the 1998 El Niño breeding season resulted from low numbers of females that used the study beach that year, but included most females with pups that were present. Paint markings and natural scarring were drawn on animal identification cards. Marks lasted from 2 to $3 \mathrm{wk}$. Some females were re-marked depending on the quality of the initial mark.

Female movements were recorded using focal sampling methodology (at 10 min intervals) during daylight hours (from 06:00 to 18:00 h) from a cliff that was about $70 \mathrm{~m}$ above and $100 \mathrm{~m}$ away, from the colony. The duration of the perinatal period, foraging trips, and visits onshore were recorded for each marked female. Females whose pups had died or disappeared were removed from the sample. If a female was recorded at the beach at the end of the day and was not found the next morning, her time of departure was assumed to have occurred at midnight (the midpoint between when observations stopped and began again) (Higgins \& Gass 1993, Francis et al. 1998, Milette \& Trites 2003). Females whose date of pupping was unknown and had remained onshore with their pups for more than $3 \mathrm{~d}$ after being marked were assumed to have not made their first post-partum trip to sea. First feeding trips and first visits onshore were analyzed independently from the rest of the data, because maternal investment is known to be significantly high during the perinatal period (Lunn \& Boyd 1993). Sample sizes represented the number of females rather than the numbers of trips and visits onshore. Thus, only mean durations of trips and visits onshore per female during the breeding season were included in the analysis. Daily counts of females were conducted at 06:00, 12:00 and 18:00 $\mathrm{h}$ for each year included in our study.

Prey abundance and oceanographic conditions. Interannual oceanographic and biological fluctuations occurred throughout the study period from 1998 to 2002. The strong 1997-1998 El Niño resulted in increased sea surface temperatures and a deepening of the thermocline, which drastically reduced primary marine productivity (McPhaden 1999, Fiedler 2002). This in turn affected the distribution and abundance of anchovy and other potential prey for sea lions. In contrast, the moderate 1999-2001 La Niña was characterized by cold surface temperatures, shallow thermoclines, and high marine productivity (Fiedler 2002), which resulted in favourable prey conditions for the sea lions. The 2002 breeding season took place during the early stages of the moderate 2002 El Niño (Moron 2002, Niquen \& Bouchon 2002).
Data on prey abundance and distribution of pelagic resources were obtained from IMARPE. These included catch per unit of effort (CPUE) indices from commercial catches of Peruvian anchovy, in addition to data on abundance and distribution of anchovy derived from hydroacoustic surveys conducted in the area between $10^{\circ} \mathrm{S}$ to $20^{\circ} \mathrm{S}$ (within which our study site was located, see Fig. 6). Hydroacoustic surveys encompassed the area between the shore and 100 to 120 nautical miles and were carried out using the echo-sounding SIMRAD EK-500 and EY-500. Abundance of anchovy from hydroacoustic surveys was estimated by IMARPE using echo integration techniques (see MacLennan \& Simmonds 1992). CPUE is often used as a measurement of relative abundance for anchovy (Ñiquen \& Bouchon 2002, Santojani et al. 2003), and was compared to the duration of sea lion foraging trips and visits onshore to test for possible relationships. CPUE indices included the catch of anchovy (in t) per hour of commercial fishing trip, per hold with fish, per registered gross vessel tonnage, and per registered gross tonnage estimated from hours of commercial fishing trip. Total catches of anchovy were affected by partial or total closed seasons enacted by the Peruvian Government to protect spawning anchovy. This typically occurred twice per year (normally between February-March and August-September). According to IMARPE (M. Niquen pers. comm.), the anchovy catch per hour of commercial fishing trip has shown the strongest correlation with assessments of anchovy biomass from hydroacoustic surveys.

Oceanographic conditions were assessed from sea surface temperatures recorded daily by IMARPE at the Coastal Laboratory of Pisco, whereas temperature anomalies were calculated from data collected since 1976 by IMARPE. Sea surface temperatures can be used as an index of environmental uncertainty (Gentry et al. 1986) and have been associated with changes in the abundance of the Peruvian anchovy (Barber \& Chavez 1986) and with changes in maternal performance in otariids (Francis et al. 1998, Lea 2002). We therefore analysed these oceanographic features to test for possible relationships with maternal attendance patterns. We also explored potential links between the distribution and abundance of prey species close to the breeding area and their frequency of occurrence in the diet of sea lions.

\section{RESULTS}

\section{Diet}

A total of 1719 otoliths were retrieved from 307 scats. All but $1.8 \%$ of the otoliths $(\mathrm{n}=31$ ) could be identified to species level. The main prey items consumed were 
Table 1. Frequencies of occurrences (\%) of the principal prey of South American sea lions during the breeding season from 1998 to 2002 at San Gallan Island. Mean values excluded the 1998 El Niño. * Occurrences of crustaceans in 2002 correspond to percentages for January 2002 only since no crustacean remains were found in scats during February 2002

\begin{tabular}{|lrcc|}
\hline Breeding season & Fish & Crustaceans & Cephalopods \\
\hline 1998 El Niño & 97.5 & 0.0 & 5.1 \\
1999 La Niña & 41.1 & 83.6 & 27.4 \\
2000 La Niña & 86.0 & 96.0 & 6.0 \\
2001 La Niña & 100.0 & 76.2 & 28.6 \\
2002 & 79.7 & $97.5^{*}$ & 9.5 \\
1999-2002 mean & 76.7 & 88.3 & 17.9 \\
\hline
\end{tabular}

fish, crustaceans and cephalopods (frequency of occurrence $76.7,88.3$ and $17.9 \%$, respectively) (Table 1), with the highest numbers of prey species consumed during 2002 (17 species) and during the 1998 El Niño (12 species). On average, 8 species $\mathrm{yr}^{-1}$ were found in scats during La Niña years (1999-2001).

Significant differences were found in the occurrences of principal prey among and within years. Only anchovy and squid occurred in the diet in all years. However, frequency of consumption of anchovy differed among years (logistic regression deviance test: year as a categorical variable, $\chi_{4}{ }^{2}=32.86, \mathrm{p}<0.001$ ), as did consumption of squid $\left(\chi_{4}^{2}=23.20, \mathrm{p}<0.001\right)$.

No differences were found in the relative occurrences of anchovy within a season in any year. Anchovy represented an average $75 \%$ of total fish occurrences (excluding the 1998 El Niño, when anchovy were scarce and other fish species were consumed at a greater frequency). When the 1998 El Niño period was included, anchovy represented an average of $68 \%$ of total fish occurrences in the diet. The only year that squid varied within a season was 1999 (logistic regression deviance test: $\chi_{1}^{2}=4.73, \mathrm{p}=0.03$ ). The pelagic squat lobster Pleuroncodes monodon represented $100 \%$ of total crustaceans in the scats, and was identified in all years except in February 2002 and during the 1998 El Niño. Its occurrence also differed among years (logistic regression deviance test: year as a categorical variable, $\chi_{3}^{2}=36.61, p<0.001$ ), but only differed within a season in 2002 when no remains were found in scats collected in February (early stages of the 2002 El Niño, see Table 1).

Important demersal species for commercial fisheries occurred at high frequencies in most years. These included the lumptail searobin Prionotus stephanophrys, Peruvian hake Merluccius gayi, and camotillo Normanichthys crockeri (mean frequency occurrence $=21.6,8.2$, and $29.2 \%$, respectively). However, differences in occurrences were observed among years (lumptail searobin logistic regression deviance test: $\chi_{3}^{2}=57.43, \mathrm{p}=0.027$; Peruvian hake: $\chi_{3}^{2}=8.82, \mathrm{p}=$ 0.032; camotillo: $\chi_{3}^{2}=9.09 \mathrm{p}=0.028$ ). The demersal cachema Cynoscion analis only occurred at high frequency $(22.2 \%)$ during the 1998 El Niño period.

\section{Maternal attendance}

A total of 3984 foraging trips and 3836 visits onshore were recorded and analyzed. This represented a mean $( \pm \mathrm{SE}) 8.77 \pm 0.24$ trips and $8.66 \pm 0.24$ visits per female in each year of the study, which did not vary significantly among years. However, the duration of foraging trips (Kruskal-Wallis $\chi_{4}{ }^{2}=133.1, \mathrm{p}<0.001$ ) and visits onshore (Kruskal-Wallis: $\chi_{4}^{2}=18.70, p<0.001$ ) differed significantly among years, even after removing the 1998 El Niño (trips: $\chi_{3}^{2}=121.97, p<0.001$; visits: $\chi_{3}^{2}=$ 8.87, $\mathrm{p}=0.031$ ) (Fig. 1, Table 2).

Mean duration of foraging trips and visits onshore were inversely related, with the longest foraging trips and shortest visits onshore occurring during the 1998 El Niño. In contrast, durations of foraging trips were the shortest during the $2000 \mathrm{La}$ Niña, while visits onshore were the longest (Fig. 1). During the $1998 \mathrm{El}$ Niño, foraging trips were about twice the mean duration of trips in subsequent years (Table 2).

In every year, duration of the first trip and visit onshore after parturition were longer than all other trips and visits (Table 3); and these durations also var-

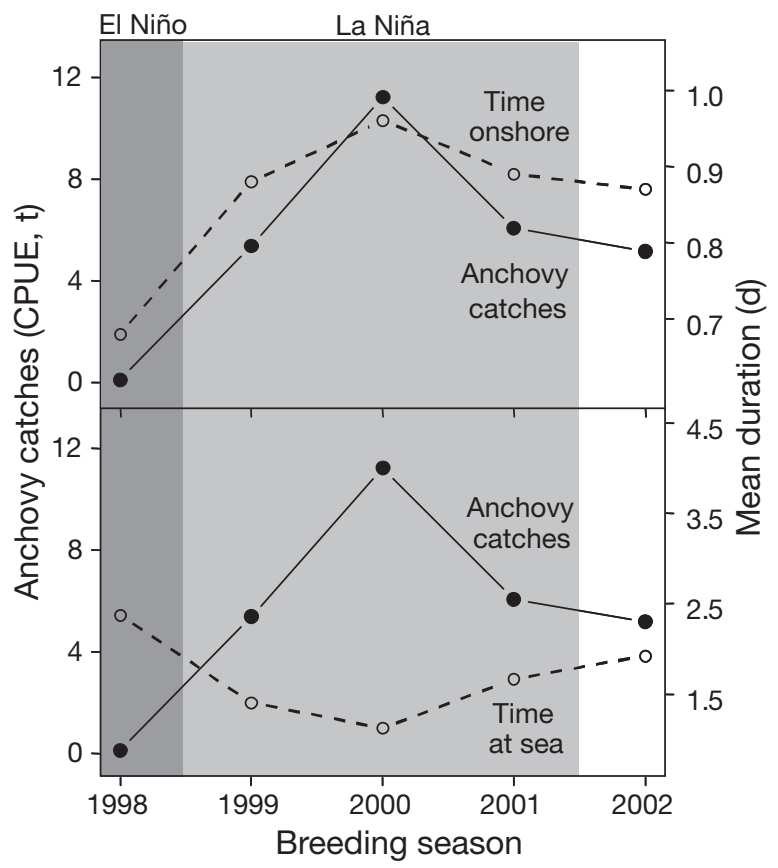

Fig. 1. Otaria flavescens. Mean duration of female trips to sea and visits onshore during breeding seasons from 1998 to 2002, contrasted with an index of prey abundance (anchovy catches per unit effort [CPUE]) 
Table 2. Otaria flavescens. Duration ( $\mathrm{d}_{\text {; }}$ mean $\pm \mathrm{SE}$, range) of foraging trips and visits onshore, and mean number of females onshore during the 1998 to 2002 breeding seasons. n: number of counts and number of females per breeding season included in the analysis

\begin{tabular}{|c|c|c|c|c|c|c|c|c|c|}
\hline \multirow[t]{2}{*}{ Breeding season } & \multicolumn{3}{|c|}{ Foraging trips -} & \multicolumn{3}{|c|}{ - Visits onshore -} & \multicolumn{3}{|c|}{ - Females } \\
\hline & Mean $\pm \mathrm{SE}$ & Range & $\mathrm{n}$ & Mean $\pm \mathrm{SE}$ & Range & $\mathrm{n}$ & Mean $\pm \mathrm{SE}$ & Range & $\mathrm{n}$ \\
\hline 1998 El Niño & $2.37 \pm 0.23$ & $0.45-4.41$ & 22 & $0.68 \pm 0.04$ & $0.43-1.21$ & 22 & $72.11 \pm 6.15$ & $13-154$ & 54 \\
\hline 1999 La Niña & $1.40 \pm 0.04$ & $0.49-2.88$ & 92 & $0.88 \pm 0.03$ & $0.28-1.62$ & 88 & $548.04 \pm 18.64$ & $287-1113$ & 63 \\
\hline 2000 La Niña & $1.12 \pm 0.03$ & $0.45-2.08$ & 122 & $0.96 \pm 0.02$ & $0.54-1.66$ & 119 & $470.15 \pm 7.22$ & $311-596$ & 60 \\
\hline 2001 La Niña & $1.67 \pm 0.07$ & $0.36-3.36$ & 117 & $0.89 \pm 0.08$ & $0.34-1.62$ & 112 & $457.90 \pm 7.43$ & $321-536$ & 43 \\
\hline 2002 & $1.92 \pm 0.06$ & $0.57-3.60$ & 107 & $0.87 \pm 0.02$ & $0.36-1.64$ & 103 & $390.19 \pm 12.01$ & $205-519$ & 47 \\
\hline 1998-2002 mean & $1.56 \pm 0.07$ & & & $0.90 \pm 0.04$ & & & $470.06 \pm 14.56$ & & \\
\hline
\end{tabular}

ied significantly among years (Kruskal-Wallis, trips: $\chi_{4}{ }^{2}$ $=91.75, p<0.001$; visits: $\chi_{4}{ }^{2}=17.35, p=0.002$ ).

The perinatal period (interval between birth and the first trip to sea) averaged $7.46 \mathrm{~d}$ over the $5 \mathrm{yr}$ of study (Table 3) and varied significantly among years (Kruskal-Wallis: $\chi_{4}^{2}=38.61, \mathrm{p}<0.001$ ). The shortest period occurred during the $1998 \mathrm{El}$ Niño and the longest during the $2000 \mathrm{La}$ Niña. During La Niña years, the perinatal period was on average $\sim 2 \mathrm{~d}$ longer than during the 1998 El Niño.

Of the 42 females marked during the $1998 \mathrm{El}$ Niño breeding season, $22 \%(\mathrm{n}=10)$ did not return to the beach after their first feeding trip and another $22 \%$ abandoned their pups after their second feeding trip. When we removed females that had lost their pups from the samples, the number of recorded foraging trips was lower during the 1998 El Niño than during other years (Fig. 2) since most pups died before the end of the breeding season (Soto et al. 2004).

During the 1998 El Niño, no trend was observed in mean time that females spent at sea until their fifth trip; from this time onwards, mean times at sea began to decrease with each subsequent trip (Fig. 2). In 1999 (the first breeding season following the strong 1997-1998 El Niño), no trend was detected in mean time spent at sea. However, mean times at sea increased throughout the breeding seasons in 2000 and 2002, and decreased in 2001 (Fig. 2). No trends were observed in the time spent onshore during the 1998 El Niño. However, for all other years (1999 to 2002), the mean time onshore decreased as the pups grew older (Fig. 2).

The proportion of time that females spent at sea per attendance cycle differed significantly among years (Kruskal-Wallis: $\chi_{4}{ }^{2}=132.05, \mathrm{p}<0.001$ ), and was greatest during the $1998 \mathrm{El}$ Niño $(71 \%)$ and lowest during the 2000 La Niña (53\%). Differences among years were also noted for the proportion of time females spent at sea during the first trip after parturition (Kruskal-Wallis: $\chi_{4}{ }^{2}=102.25, \mathrm{p}<0.001$ ).

There was considerable variability in the duration of foraging trips among females within a year. Variability in time spent at sea was highest during the $1998 \mathrm{El}$ Niño (coefficient of variation $[C V]=45.15 \%$ ) and lowest during the 2000 La Niña $(25.89 \%)$. Such variability was statistically consistent among years (CV $=32.33 \%$ for all years combined). However, the lack of statistical significance may have been related to the small sample size obtained from 1998 (El Niño) and the lower number of females with pups whose foraging trips could be recorded that year (see Fig. 2). Variability in the duration of visits onshore was similar among years $(26.94 \%)$.

In all years except 2000, the proportion of time that females spent at sea was significantly correlated with the duration of attendance cycles each year (1998 El

Table 3. Otaria flavescens. Duration $\left(\mathrm{d}_{\text {; }}\right.$ mean $\pm \mathrm{SE}$, range) of the perinatal period, first foraging trip and first visit onshore during the 1998 to 2002 breeding seasons at the Ballestas Islands. n: number of females per breeding season included in the analysis

\begin{tabular}{|c|c|c|c|c|c|c|c|c|c|}
\hline \multirow{2}{*}{ Breeding season } & \multicolumn{3}{|c|}{$\ldots$ Perinatal period $ـ$} & \multicolumn{3}{|c|}{- First trip -} & \multicolumn{3}{|c|}{ First visit } \\
\hline & Mean $\pm \mathrm{SE}$ & Range & $\mathrm{n}$ & Mean \pm SE & Range & $\mathrm{n}$ & Mean $\pm \mathrm{SE}$ & Range & $\mathrm{n}$ \\
\hline 1998 El Niño & $5.72 \pm 0.36$ & $1.26-7.24$ & 26 & $2.98 \pm 0.29$ & $0.83-8.29$ & 32 & $1.01 \pm 0.11$ & $0.27-2.43$ & 32 \\
\hline 1999 La Niña & $7.54 \pm 0.10$ & $3.65-12.00$ & 114 & $1.56 \pm 0.07$ & $0.30-4.00$ & 113 & $1.25 \pm 0.05$ & $0.32-3.37$ & 101 \\
\hline 2000 La Niña & $7.69 \pm 0.10$ & $4.43-10.34$ & 104 & $1.32 \pm 0.05$ & $0.33-3.72$ & 143 & $1.23 \pm 0.04$ & $0.30-2.66$ & 128 \\
\hline 2001 La Niña & $7.23 \pm 0.11$ & $5.00-10.00$ & 80 & $1.69 \pm 0.06$ & $0.28-3.74$ & 117 & $1.11 \pm 0.04$ & $0.30-3.00$ & 113 \\
\hline 2002 & $7.21 \pm 0.14$ & $4.75-10.71$ & 65 & $2.21 \pm 0.98$ & $0.49-5.74$ & 104 & $1.03 \pm 0.04$ & $0.28-2.45$ & 96 \\
\hline 1998-2002 Mean & $7.46 \pm 0.39$ & & & $1.66 \pm 0.08$ & & & $1.16 \pm 0.06$ & & \\
\hline
\end{tabular}




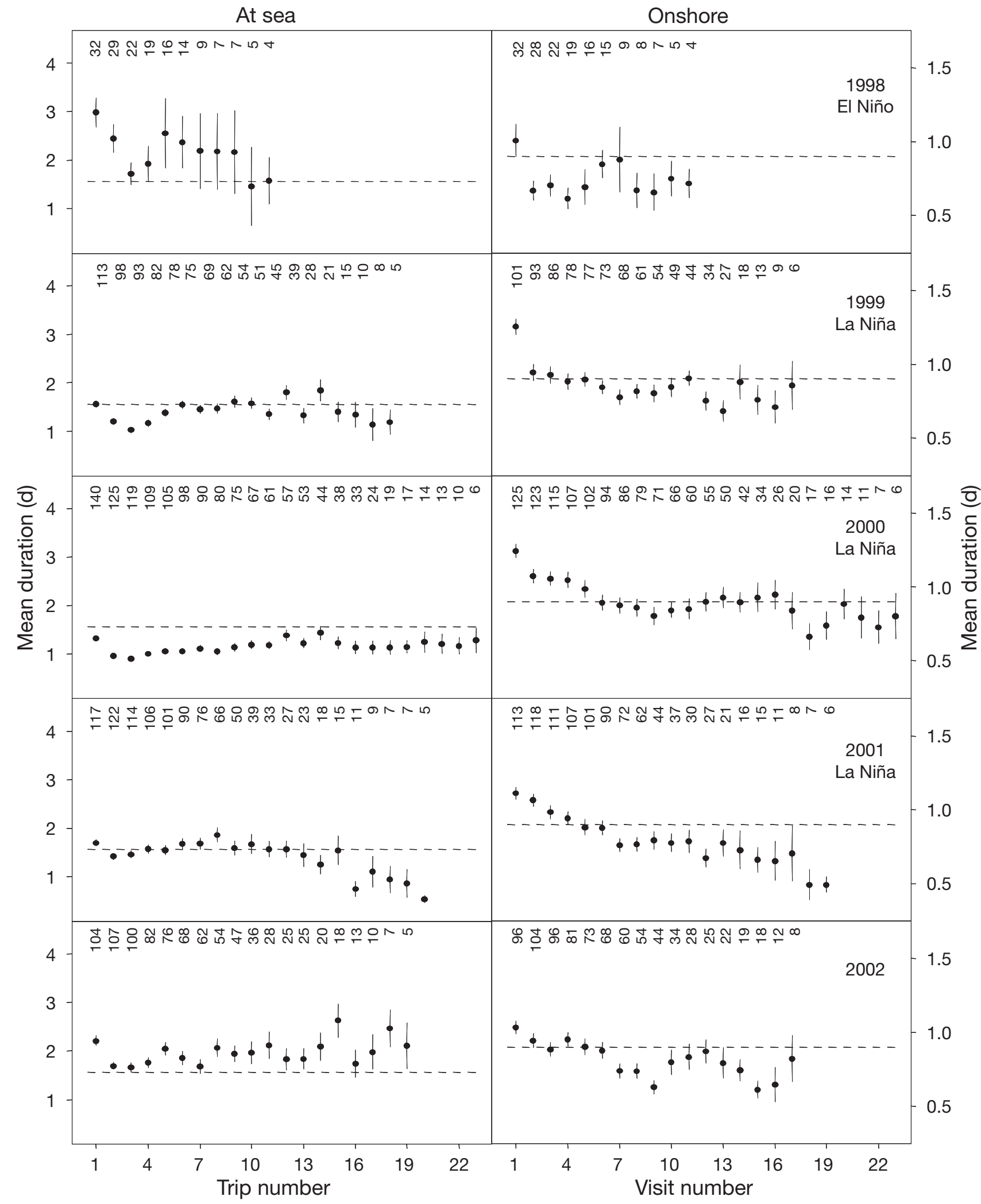

Fig. 2. Otaria flavescens. Mean duration \pm SE of female trips to sea and visits onshore during breeding seasons from 1998 to 2002. Sample sizes (number of individual females) indicated at the top of each panel. Dashed lines represent grand mean of trips and visits, respectively, excluding the 1998 El Niño. Trip numbers show the trips that females made after parturition from the 1st to the 23rd trip, while visits indicate time spent onshore 
Niño: Pearson, $r=0.742, \mathrm{p}<0.001, \mathrm{n}=22 ; 1999: r=$ 0.372, $\mathrm{p}<0.001, \mathrm{n}=91 ; 2000: r=0.097, \mathrm{p}=0.292, \mathrm{n}=$ 119; 2001: $r=0.548, \mathrm{p}<0.001, \mathrm{n}=111 ; 2002: r=0.492$, $\mathrm{p}<0.001, \mathrm{n}=103)$. Thus, longer attendance cycles generally reflected longer periods of time at sea. No relationship was detected between the time spent at sea and time spent onshore during previous or subsequent visits.

Time of arrival onshore varied significantly among years $\left(\chi_{12}^{2}=112.93, p<0.001\right)$, but did not differ significantly among the La Niña years (1999-2001). The time of arrival during La Niña was not random during the hours of observation (06:00 to $18: 00 \mathrm{~h}$; pooled data: $\chi_{3}^{2}=310.70, p<0.001$ ) (Fig. 3). In general, most females arrived after midday in all years except during the 1998 El Niño, when they arrived more frequently before midday.

Arrivals during La Niña occurred mostly at night and dawn rather than during the day time (2000: $\chi_{1}^{2}=$ 29.43, p < 0.001, 57.14\%; 2001: $\chi_{1}^{2}=4.15$, $\mathrm{p}=0.042,53.14 \%)$ except in $1999(48.41 \%)$ when no differences were observed. In contrast, most females arrived during the daytime in 1998 (El Niño: 63.54\%) rather than at night and dawn $\left(\chi_{1}^{2}=13.26\right.$, p < $0.001,36.46 \%)$.

Timing of departures from land during daylight hours varied significantly among years $\left(\chi_{12}^{2}=148.21, \mathrm{p}<0.001\right)$. Significant differences were also observed during $\mathrm{La}$ Niña years $(1999-2001)\left(\chi_{6}^{2}=19.55, \mathrm{p}=\right.$ 0.003). In general, most females departed in the morning in all years except during the 1998 El Niño when most females departed at the end of the day (Fig. 3).

Most departures between 1998 and 2002 occurred at night and dawn rather than during daylight (mean \pm SE, night: $72.23 \pm$ $3.74 \%$; day: $27.77 \pm 3.74 \%$ ). Departures outnumbered arrivals at night and dawn in all years (departures: $72.23 \pm 3.74 \%$; arrivals: $48.87 \pm 3.46 \%$ ).

\section{Numbers of females onshore}

Mean numbers of females that were onshore during the breeding season (based on counts at 06:00 h) varied significantly among years (Kruskal-Wallis: $\chi_{4}{ }^{2}=$ 159.71, $\mathrm{p}=0.001$ ). Numbers fell from a mean 885 females before the 1997-1998 El Niño (Soto et al. 2004) to 72 during the El Niño in 1998, increased again to 548 females in 1999 after El Niño, before falling once more to 390 in 2002 (Table 2). One major difference during the 1998 El Niño (as opposed to other years such as La Niña in 2000) was the low numbers of females that were onshore during the breeding season, and the drastic abandonment of the breeding beaches (Fig. 4). Numbers of females onshore during non-El Niño years did not vary significantly before or after the breeding season (K. Soto pers. obs.).

Mean numbers of females onshore varied significantly throughout the day for each year of the study (based on daily counts at 06:00, 12:00 and 18:00 h) (Kruskal-Wallis, 1999: $\chi_{2}{ }^{2}=56.40, \mathrm{p}<0.001 ; 2000: \chi_{2}{ }^{2}$ $=114.16, \mathrm{p}<0.001 ; 2001: \chi_{2}^{2}=48.31, \mathrm{p}<0.001 ; 2002$ : $\left.\chi_{2}^{2}=26.59, \mathrm{p}<0.001\right)$. In general, numbers tended to be higher early in the morning, drop to a minimum around midday, and increase to a maximum towards the end of the day when most of the arrivals were recorded (Fig. 3). Each morning, most of the females and their pups moved towards the water's edge to

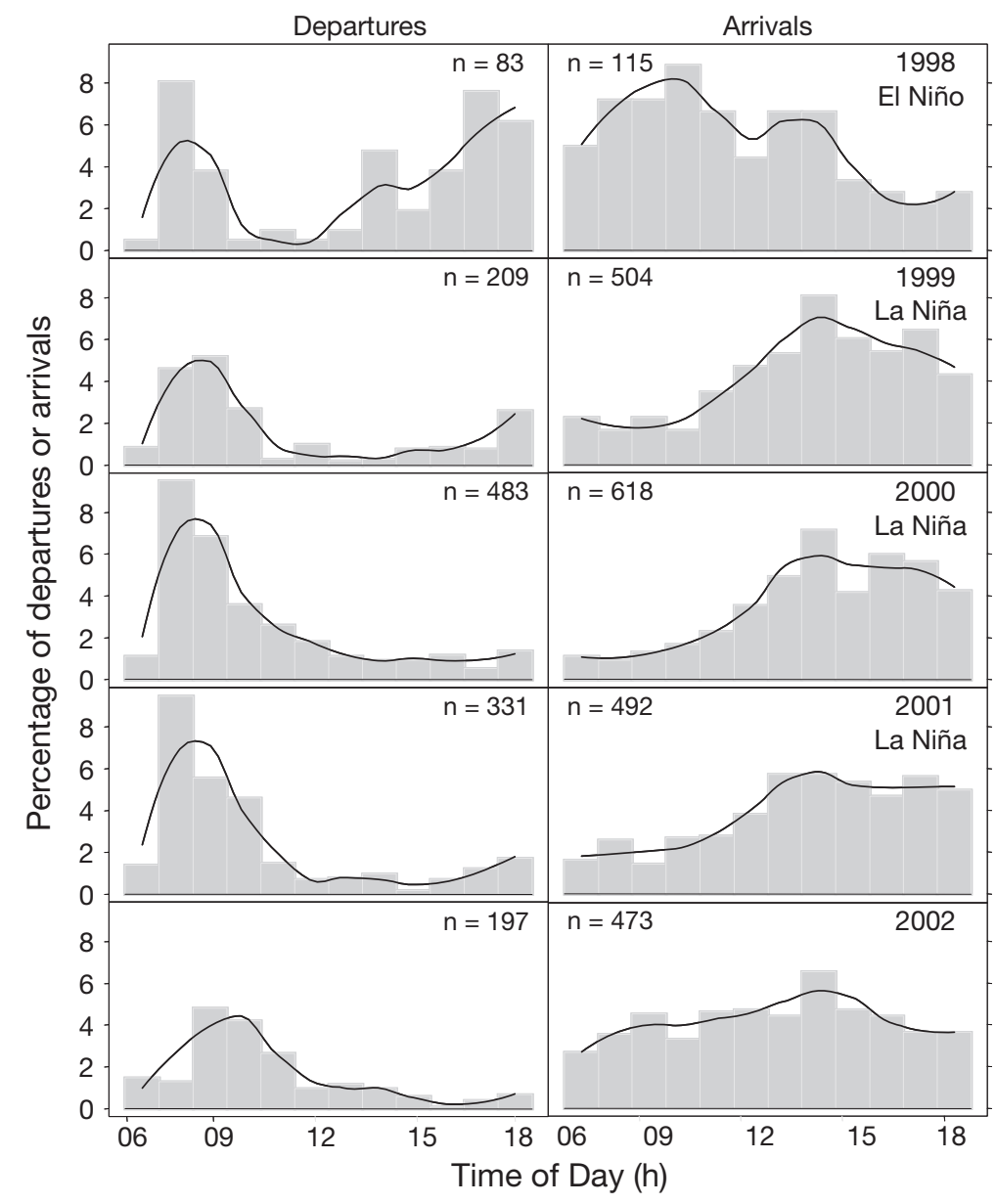

Fig. 3. Otaria flavescens. Timing of arrivals and departures of lactating females observed during daylight hours from 1998 to 2002 at Ballestas Islands. Percentages calculated as number of arrivals (or departures) $\mathrm{h}^{-1}$ as a percent of total (day and night) arrivals (or departures). Data smoothed with loess curves (solid lines). Total numbers of documented arrivals and departures indicated in each panel 


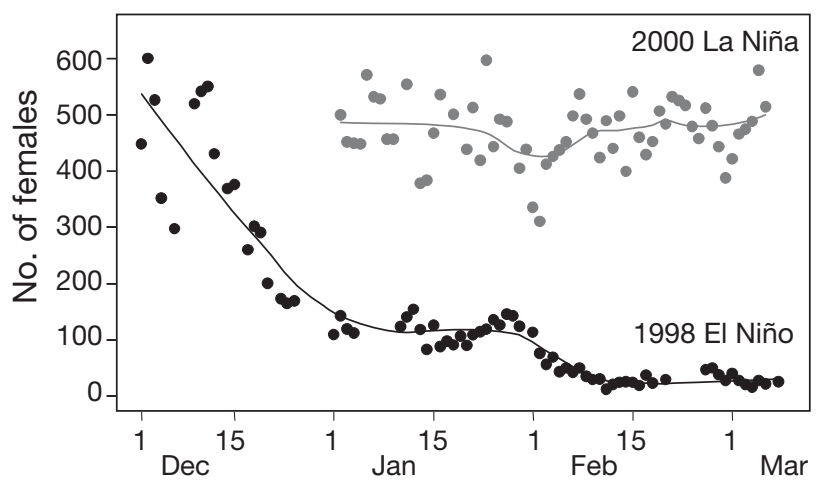

Fig. 4. Otaria flavescens. Daily number of females onshore (based on counts at 06:00 h) from the 1998 El Niño contrasted with the 2000 La Niña (similar to other non-El Niño years).

Data smoothed with loess curves

occupy the shoreline, presumably to avoid overheating as soon as the sunlight fell on the beach (at approximately 07:30 h). Other females abandoned the beach at this time, as noted by the high number of recorded departures. Females did not make such movements during cloudy days. Instead, animals tended to increase the spacing between them. Although no significant differences were observed in the number of females onshore throughout the day during the 1998 El Niño, the highest numbers occurred at midday, with lower numbers registered at the end of the day and minimum numbers in the morning.

Differences between the numbers of females at the end of each day $(18: 00 \mathrm{~h})$ and the following morning $(06: 00 \mathrm{~h})$ indicated that most females departed at night, which is consistent with our observations that the highest numbers of marked females departed overnight.

\section{Prey abundance, oceanographic conditions and maternal attendance patterns}

Females appeared to adjust their attendance cycles in response to changes in prey abundance (Fig. 1), as shown by the inverse relationship between the time spent at sea and the abundance of prey (measured as anchovy CPUE, shown in Table 4). Conversely, females spent more time onshore as abundance of prey increased (Table 4).

Durations of foraging trips correlated positively with sea surface temperature anomalies (Pearson, $r=$ 0.896, $\mathrm{p}=0.039, \mathrm{n}=5$ ) (Fig. 5). In contrast, durations of visits onshore were inversely correlated with tem-

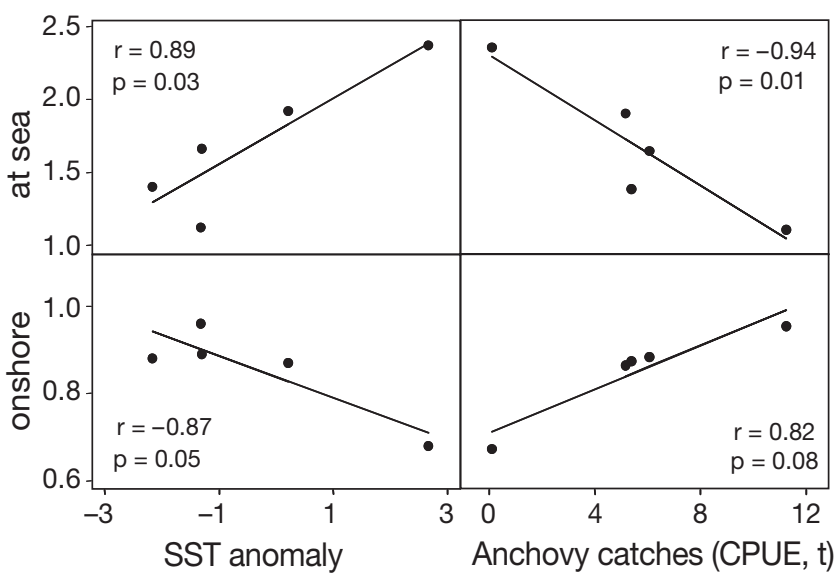

Fig. 5. Otaria flavescens. Relationship between time allocation of females (at sea versus onshore) and sea surface temperature (SST) anomalies (left panels) and anchovy CPUE (catch per hour of trip) (right panels)

perature anomalies ( $r=-0.887, \mathrm{p}=0.051, \mathrm{n}=5)$ (Fig. 5). Foraging trips were thus longer and visits onshore were shorter when temperature anomalies were positive (such as during El Niño), whereas trips were shorter and visits onshore were longer when anomalies were negative (as during La Niña).

\section{DISCUSSION}

There appeared to be a strong relationship between diet, maternal attendance, and the availability of prey for South American sea lions in the Peruvian marine ecosystem. Types and proportions of prey consumed as well as the maternal attendance cycles varied according to interannual shifts in the abundance and distribution of fish and crustaceans. However, maternal flexibility was insufficient during the 1997-1998 El Niño to compensate for acute prey shortages, which resulted in females spending prolonged times at sea that exceeded the fasting abilities of their pups and caused high mortalities due to starvation.

Table 4. Relationship between an index of prey abundance (anchovy catches from commercial fisheries, CPUE) and the duration of the maternal attendance cycle in sea lions (time at sea and time onshore). *Estimated from total hours of trip

\begin{tabular}{|c|c|c|c|c|c|}
\hline \multirow[t]{2}{*}{ CPUE } & \multicolumn{3}{|c|}{ Time at sea } & \multicolumn{2}{|c|}{ Time onshore } \\
\hline & $\mathrm{r}$ & $\mathrm{p}$ & $\mathrm{n}$ & $\mathrm{r}$ & $\mathrm{p} \quad \mathrm{r}$ \\
\hline Catch per hours of trip & -0.946 & 0.015 & 5 & 0.820 & 0.080 \\
\hline Catch per hold with fish & -0.832 & 0.081 & 5 & 0.874 & 0.052 \\
\hline Catch per registered gross vessel tonnage & -0.990 & 0.001 & 5 & 0.897 & 0.039 \\
\hline Catch per registered gross vessel tonnage & -0.955 & 0.011 & 5 & 0.815 & 0.093 \\
\hline
\end{tabular}




\section{Diet}

South American sea lions fed mainly on fish, crustaceans and cephalopods, but the frequency of occurrence of each prey group differed among and within seasons. Anchovy and the pelagic squat lobster were the main prey consumed by sea lions during the 19992001 La Niña. However, the spatial distribution and abundance of anchovy and lobster varied in those years with respect to the breeding rookery (despite being close to the surface) (Fig. 6). Interestingly, occur-
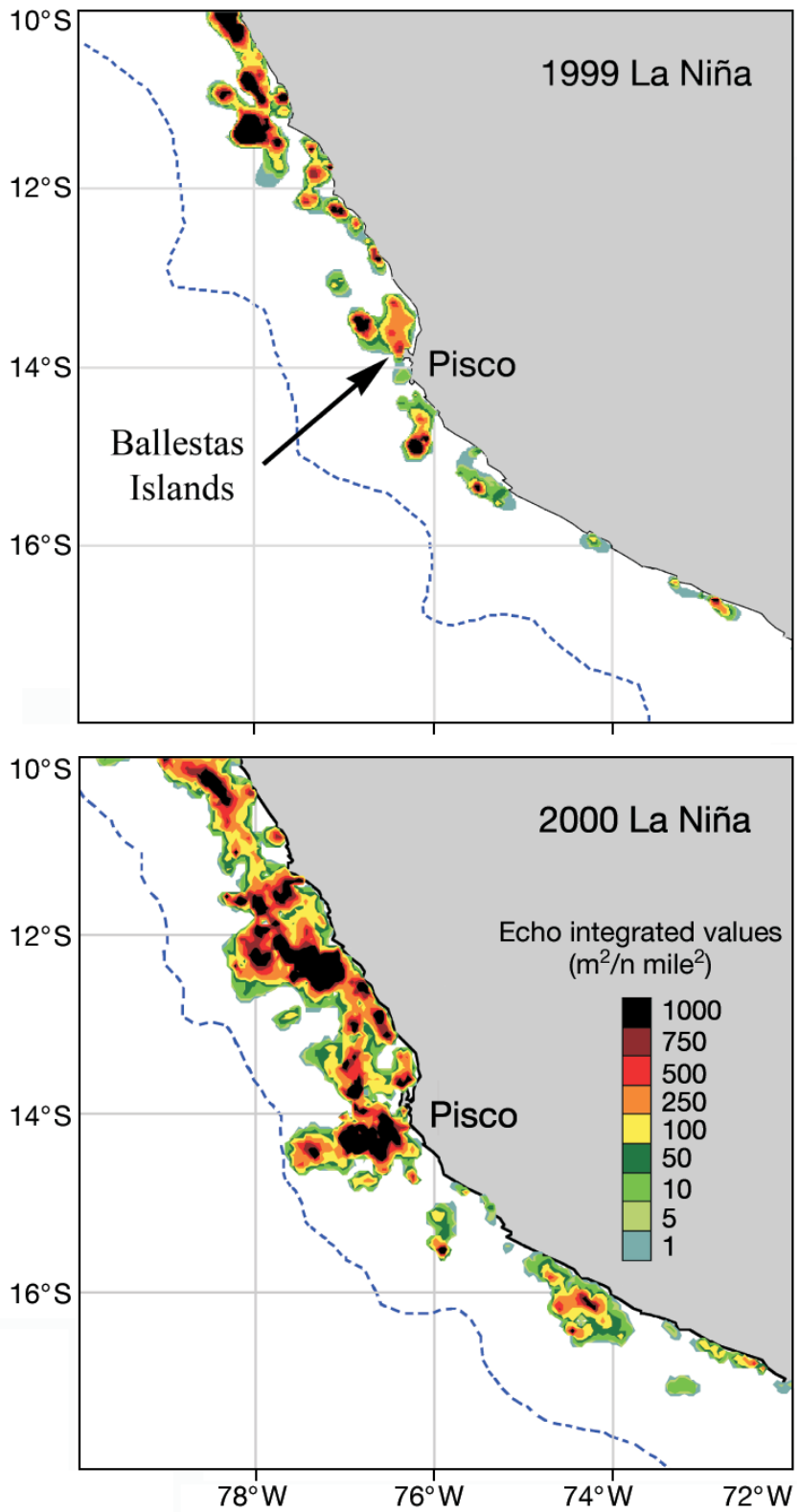

Fig. 6. Engraulis ringens. Hydroacoustic survey data on distribution and abundance of anchovy around Ballestas Islands during La Niña. Dashed lines indicate limits of surveys. Adapted from Castillo $(1999,2001)$ rence of anchovy and squat lobster in the diets increased as prey became more abundant close to the rookery (Castillo et al. 1999, 2001, IMARPE 2002, Castillo et al. 2004) (Fig. 6).

Sea lions fed on a variety of prey when their principal prey were scarce, such as during the El Niño in 1998 and 2002. High occurrences of demersal species in the diet during these years suggested that sea lions foraged at deeper depths than normal. The only time the pelagic squat lobster was not found in the sea lion diet was during the 1998 El Niño and in February 2002 (early stages of the moderate 2002 El Niño). This was probably due to the preference of squat lobsters for colder waters (Paredes \& Elliot 1997), and was consistent with observations from hydroacoustic research surveys that squat lobsters were scarce near the breeding rookery during warm episodes (see IMARPE 2002).

Sea lions appear to have foraged on their preferred prey according to its relative abundance in the marine environment. Strong preferences for prey were reflected by dominant occurrences of these resources in the diet of sea lions. Scarcity of resources in the marine ecosystem was also reflected by low occurrences in their diet. This apparent relationship between diet and the distribution and abundance of principal prey (as measured from hydroacoustic surveys and commercial catches) suggests that the South American sea lion diet is a good indicator of the relative distribution and abundance of marine resources in the Peruvian marine ecosystem.

\section{Maternal attendance patterns and prey abundance}

Perinatal period

The number of days that a mother spends with her newborn before departing on her first feeding trip has been proposed to be directly linked to the availability of prey and energy reserves she acquired before parturition (Bowen 1991). In theory, time spent on shore is a function of body size and the rate at which a female's fat reserves are depleted to produce milk and nourish her pup (see Boness et al. 1994). The length of the perinatal period likely increases as feeding conditions improve, but presumably cannot extend beyond some upper asymptotic level that is set by inherent physical and physiological constraints placed on the female.

In our study, the mean duration of the perinatal period during years when prey were not restricted was similar to that reported for South American sea lions along the Atlantic coast (Campagna \& Le Boeuf 1988a), as well as for other species of sea lions (Trillmich 1986, Ono et al. 1987, Higgins et al. 1988, Higgins \& Gass 1993, Milette \& Trites 2003). However, the perinatal 
period was significantly shorter during El Niño in 1998, implying that initial female body condition was greatly reduced compared to other years and probably led to faster depletion of scarce maternal fat reserves. Such a short perinatal period might have significantly increased newborn mortality if pups failed to initially gain enough energy reserves to survive their first fast while their mothers foraged at sea. Similar reduced perinatal attendances due to reductions in prey abundance have been reported for other otariids (see Ono et al. 1987, Lunn et al. 1993).

Time at sea

Changes in prey quality and abundance appear to have affected the duration of foraging trips (Figs. 1 \& 5). For example, shorter foraging trips were recorded during the 2000 La Niña year when prey were more abundant and closer to the breeding beach (Castillo et al. 2001) (Fig. 6). Mid- to high-abundances of prey were located further away from the breeding beaches during the 1999 La Niña year (Castillo et al. 1999, 2004) (Fig. 6), and resulted in slightly longer foraging trips. However, the longest feeding trips occurred during the 1998 El Niño when the thermocline deepened (by more than $100 \mathrm{~m}$ ) (Pizarro 1997, Sánchez et al. 2000), and females had to dive to greater depths and/or travel longer distances from the rookery to follow the migrating anchovy to cooler areas of southern Peru (Ñiquen \& Bouchon 2002). Such changes in time spent at sea in response to changes in prey availability have also been reported for several other otariid species (Limberger et al. 1983, Trillmich et al. 1986, Ono et al. 1987, Costa et al. 1991, DeLong \& Antonelis 1991, Boyd 1999).

Boyd et al. (1991) considered 2 factors that might set the duration of female foraging trips. One was that females need to attain a minimum amount of energy before returning onshore to nurse their pups. The second was that the time spent away from the rookery must not exceed the ability of the pups to fast, regardless of the energy gained. If the former factor occurs, females may return before or after a determined time limit depending on the availability of prey (Lunn et al. 1993). However, if a minimum amount of energy is gained before this time limit, females may continue to forage until they reach the time limit set by the fasting ability of pups or their maximum storage capacity (Lunn et al. 1993).

The length of foraging trips for female South American sea lions seems to be mainly determined by storage capacity rather than by a set time limit (i.e. as dictated by pup fasting ability). During La Niña in 2000, when prey abundance was the highest, females pre- sumably reached their storage capacities faster than in other years based on the shortness of their trips. If trip durations were time limited, trips would be expected to have been of similar durations in good years such as during La Niña years. Instead, average trip durations correlated with the abundance and distribution of prey, such that time at sea was reduced as prey became more abundant and were located closer to the rookery (Figs. $5 \& 6$ ).

Flexibility in duration of maternal foraging trips observed for South American sea lions seemed to depend on a combination of environmental, physical and physiological constraints. Females presumably require a minimum time at sea to replenish their resources and/or satisfy a minimum gain of energy. Such a restriction is probably determined by physiological and physical constraints (Boyd et al. 1991, Thompson et al. 1998) as well as by prey abundance. Similarly, there must also be a maximum time a female can spend at sea before her pup starves, which must be a function of the fasting abilities of pups, female storage capacity, and the abundance of prey. However, in extreme circumstances (such as during the strong 1997-1998 El Niño when prey were reduced), females may have to extend the time they spend at sea to ensure their own survival and forego the needs of their pups.

The duration of foraging trips recorded during years when prey were not restricted were similar to values obtained for South American sea lions at the Falkland Islands (Thompson et al. 1998). However, South American sea lions from Argentina (Campagna \& Le Boeuf 1988a, Campagna et al. 2001) spent as much as twice the time foraging as did the sea lions we observed. Since distance to foraging grounds is an important component of trip duration (Boyd 1999), and time at sea increases with travel distance (Boyd 1999), these longer trip durations in Argentina may indicate that greater distances were travelled or longer times were spent foraging to satisfy energy requirements.

\section{Time onshore}

The time that females spent onshore after foraging also varied according to the abundance of prey (Figs. 1 $\& 5)$. Shorter visits onshore occurred when prey abundance was lower, as observed during the 1998 El Niño, and longer visits occurred when prey was not restricted (as during La Niña). However, the time spent onshore by females of other species of otariids appears to be less sensitive to prey reductions than the time spent at sea. For several species, shorter times onshore during periods of prey shortage have not differed significantly from values obtained in normal years (see Ono et al. 1987). 


\section{Arrivals and departures}

Most females departed at night, and the number of females departing at night always outnumbering those arriving at night. This occurred in all years of our study, and was further supported by the observation that higher numbers of females were onshore at the end of each day than were present the following morning. These patterns of arrival and departure suggest that female South American sea lions foraged mostly at night and dawn, when anchovy were closer to the surface and were more accessible to the sea lions (Arntz et al. 1991). Such nocturnal foraging patterns have also been reported for the sympatric South American fur seal (Trillmich et al. 1986), which also preys mainly on anchovy (Arias-Schreiber 2003).

Although most females departed at night, some waited until the early morning daylight hours and returned the following day during the afternoon (Fig. 3). Leaving before the sun is at its peak and returning afterwards is probably an effective strategy to reduce thermal stress during the hot midday hours. Otariids that inhabit the tropics and subtropics have had to behaviourally adapt to intense solar radiation and high air temperatures during breeding seasons (Campagna \& LeBoeuf 1988b). However, many of the adaptive behaviours that reduce thermal stress can compromise reproductive success and mating strategies (e.g. aggressiveness) (Trillmich et al. 1986, Campagna \& LeBoeuf 1988b, Soto et al. 2004).

The general pattern of arrivals and departures that we observed differed during the 1998 El Niño compared to other years of observation. Similar patterns of arrivals and departures were observed for the South American fur seal during an earlier El Niño in 1982-1983 (Trillmich. et al. 1986). The most striking difference during El Niño was the tendency for greater numbers of females to arrive onshore before midday, when higher air temperatures and solar radiation increased the risks of overheating on land. Although remaining on land during daylight may incur thermoregulatory costs (Soto et al. 2004), avoiding the hot hours by foraging during the day on reduced prey during El Niño might be energetically more expensive than nocturnal foraging since anchovy are normally located at deeper depths during the day (Arntz et al. 1991).

\section{Effects of acute prey shortages}

Assessments of pelagic resources by hydroacoustic research surveys were not conducted by IMARPE during the 1997-1998 El Niño breeding season. However, data from landings of commercial fisheries indicated that anchovy catches were minimal at that time because of deepening of the thermocline (Niquen \& Bouchon 2002). Female sea lions also appeared to secure limited catches at that time based on poor body conditions and extended lengths of observed foraging trips (Fig. 5). Females failed to meet their own energy requirements or those of their pups during El Niño, and appeared to have had no alternative but to abandon their pups or nurse them with milk of insufficient quality and quantity after spending long periods at sea.

The first foraging trips made by females following parturition tend to be longer than subsequent trips, and seem to reflect the time needed for mothers to replenish fat reserves depleted during the perinatal period. However, during the El Niño in 1998, the first foraging trips were exceptionally long while the perinatal period was significantly short compared to other years (Table 3). Although most females abandoned their pups during El Niño in 1998, it did not ensure their own survival. High numbers of visibly emaciated females died at several rookeries along the Peruvian coast in February 1998 during the peak of El Niño (K. Soto pers. obs.). Similarly, many pups were unable to successfully fast between infrequent visits of their mothers onshore, and subsequently starved to death (Soto et al. 2004). One emaciated pup attempted to continuously take milk from other females, but died after waiting $9 \mathrm{~d}$ for its mother. She returned $2 \mathrm{~d}$ after its death and was also visibly emaciated.

Another compounding factor for the sea lions during the 1997-1998 El Niño was that the energy content of anchovy was lower than in other years (Alamo \& Espinoza 1998). This would have reduced the energy intake per unit of prey captured by sea lions. The reduced abundance and low quality of prey at deeper depths than normal would have also caused sea lions to expend more energy per unit of prey consumed. Moreover, poor body condition likely further reduced female diving abilities and decreased their foraging success.

Although some species of otariids have been shown to increase their diving effort near rookeries when prey is limited (Lea et al. 2002), it is not clear whether the longer foraging trips of South American sea lions noted during El Niño in 1998 were due to increased foraging effort associated with swimming greater distances from the rookery, increased rates of diving closer to the rookery, or a combination of both. In at least some instances, long distances were travelled since a number of known females who abandoned their pups were sighted as far as $250 \mathrm{~km}$ south of the breeding rookery (K. Soto pers. obs.). What was apparent was that foraging behaviour of the sea lions could not sufficiently compensate for acute reductions of prey. 


\section{Numbers of females onshore}

Numbers of females onshore during the breeding season decreased dramatically during the 1997-1998 El Niño (Fig. 4). Females progressively abandoned the rookery throughout the El Niño starting in November 1997, and no animals were observed at the end of the breeding season in March 1998. High adult mortality and the loss of entire young cohorts during this El Niño (Soto et al. 2004) accounted for the low number of survivors that remained in April 1998. Although favourable oceanographic conditions followed in the years subsequent to the 1997-1998 El Niño, population recovery might take many years due to the time required for females to reach the age of reproduction and successfully pup. Should another El Niño of strong magnitude occur before the population has had sufficient time to rebuild, recovery of the remaining population of sea lions may be seriously compromised.

\section{CONCLUSIONS}

Our study demonstrated that South American sea lion maternal responses and diets reflected interannual fluctuations of the Peruvian upwelling ecosystem, and suggested that these sea lions may be good indicators of relative changes in the distribution and abundance of marine resources. Although dramatic changes in the Peruvian marine ecosystem due to the occurrence of El Niño and La Niña events are extreme compared to fluctuations in other marine ecosystems, the responses of apex predators such as South American sea lion provide important insights into behavioural adaptations - and limitations of those adaptations - that might have evolved to cope with rapid changes in the ecosystem and uncertainty in prey distribution and abundance.

The fact that behavioural measurements of apex predators may be considered to be good proxies for abundance and distribution of prey, as well as for oceanographic features, is promising and opens new windows for the implementation of research using marine mammals as data collectors. The integration of biological and oceanographic information has the potential to provide a better understanding of the dynamics of the marine ecosystem and their influence in shaping the life history of apex predators.

Acknowledgements. We thank: the Instituto del Mar del Peru (IMARPE) for logistical and field support provided throughout the study; M. Niquen and E. Diaz for providing unpublished data of anchovy landings in Peruvian waters; $M$. Gutierrez for data from anchovy hydroacoustic surveys in Peru; J.C. Marquez for data and analysis of sea lion's diet;
IDEAWILD for logistical support; PROABONOS for additional logistical support and permission to work at the Ballestas Islands. We thank our field team, especially $\mathrm{R}$. Manrique, Pele, Ximena, Fernando, Cynthia, Angel, Francesca and Christian, as well as M. Schuler for helping with maps and graphics and our colleagues at the Marine Mammal Research Unit, University of British Columbia especially D. Tollit, V. Deckee, M. Lea, A. Winship and D. Rosen for constructive comments on the manuscript. Support was provided to AWT from the North Pacific Marine Science Foundation through the North Pacific Universities Marine Mammal Research Consortium. We gratefully acknowledge constructive suggestions received from A. Sinclair and anonymous reviewers that improved our manuscript.

\section{LITERATURE CITED}

Alamo A, Espinoza J (1998) Variaciones alimentarias en Engraulis ringens y otros recursos pelágicos durante Invierno-Primavera de 1997. Inf Inst Mar Peru 130:45-52

Arias-Schreiber M (2003) Prey spectrum and feeding behaviour of two sympatric pinnipeds (Arctocephalus australis and Otaria flavescens) in relation to the 1997-98 ENSO in southern Peru. MSc thesis, University of Bremen

Arias-Schreiber M, Rivas C (1998) Distribución, tamaño y estructura de las poblaciones de lobos marinos Arctocephalus australis y Otaria byronia en el litoral peruano en Noviembre 1996 y Marzo 1997. Inf Prog Ins Mar Peru 73:17-32

Arntz W, Pearcy WG, Trillmich F (1991) Biological consequences of the 1982-83 El Niño in the Eastern Pacific. In: Trillmich F, Ono KA (eds) Pinnipeds and El Niño: responses to environmental stress. Springer Verlag, New York, p 22-42

Barber RT, Chavez FP (1986) Ocean variability in relation to living resources during the 1982-83 El Niño. Nature 319:279-285

Boness DJ, Bowen WD, Oftedal OT (1994) Evidence of a maternal foraging cycle resembling that of otariid seals in a small phocid, the harbor seal. Behav Ecol Sociobiol 34:95-104

Bowen WD (1991) Behavioural ecology of pinniped neonates. In: Renouf D (ed) The behaviour of pinnipeds. Chapman \& Hall, London, p 66-127

Boyd IL (1999) Foraging and provisioning in Antarctic fur seals: interannual variability in time-energy budgets. Behav Ecol 10:198-208

Boyd IL, Arnbom T (1991) Diving behavior in relation to water temperature in the southern elephant seal: foraging implications. Polar Biol 11:259-266

Boyd IL, Lunn NJ, Barton T (1991) Time budgets and foraging characteristics of lactating Antarctic fur seals. J Anim Ecol 60:577-592

Boyd IL, Arnould JPY, Barton T, Croxall JP (1994) Foraging behaviour of Antarctic fur seals during periods of contrasting prey abundance. J Anim Ecol 63:703-713

Boyd IL, Staniland IJ, Martin AR (2002) Distribution of foraging by female Antarctic fur seals. Mar Ecol Prog Ser 242:285-294

Campagna C (1985) The breeding cycle of the Southern sea lion, Otaria byronia. Mar Mamm Sci:210-218

Campagna C, Le Boeuf BJ (1988a) Reproductive behaviour of southern sea lions. Mar Mamm Sci 104:233-261

Campagna C, LeBoeuf BJ (1988b) Thermoregulatory behaviour of southern sea lions and its effect on mating strategies. Behaviour 107:73-90

Campagna C, Werner R, Karesh W, Marin MR, Koontz F, 
Cook R, Koontz C (2001) Movements and location at sea of South American sea lions (Otaria flavescens). J Zool Lond 257:205-220

Castillo R, Peraltilla S, Herrera N (1999) Biomasa de los principales recursos pesqueros durante el verano 1999. Crucero BIC José Olaya Balandra 9902 03, de tumbes a tacna. Inf Inst Mar Peru 147:31-45

Castillo R, Peraltilla S, Marin D (2001) Distribución de los once recursos pesqueros de mayor abundancia en el mar peruano durante el verano 2000. Inf Inst Mar Peru 159: $7-21$

Castillo R, Gutierrez M, Peraltilla S (2004) Distribución de nueve especies pelágicas abundantes en el mar peruano durante el verano 2001. Inf Inst Mar Peru 32:37-45

Costa DP, Antonelis GA, DeLong RL (1991) Effects of El Niño on the foraging energetics of the California sea lion. In: Trillmich F, Ono KA (eds) Pinnipeds and El Niño: responses to environmental stress. Springer Verlag, New York, p 156-165

Dellinger T, Trillmich F (1988) Estimating diet composition from scat analysis in otariid seals (Otariidae): is it reliable? Can J Zool 66:1865-1870

DeLong RL, Antonelis GA (1991) Impact of the 1982-1983 El Niño on the northern fur seal population at San Miguel Island, California. In: Trillmich F, Ono KA (eds) Pinnipeds and El Niño: responses to environmental stress. Springer Verlag, New York, p 75-83

Fiedler PC (2002) Environmental change in the eastern tropical Pacific Ocean: review of ENSO and decadal variability. Mar Ecol Prog Ser 244:265-283

Francis J, Boness DJ, Ochoa-Acuña H (1998) A protracted foraging and attendance cycle in female Juan Fernández fur seals. Mar Mamm Sci 14:552-574

García-Godos I (2001) Patrones morfológicos del otolito sagitta de algunos peces óseos del mar peruano. Bol Inst Mar Peru 20:1-70

Gentry RL, Costa DP, Croxall JP, David JHM and 5 others (1986) Synthesis and conclusions. In: Gentry RL, Kooyman GL (eds) Fur seals: maternal strategies on land and at sea. Princeton University Press, Princeton, NJ, p 220-264

Guinet C, Dubroca L, Lea MA, Goldsworthy S, Cherel Y, Duhamel G, Bonadonna F, Donnay JP (2001) Spatial distribution of foraging in female Antarctic fur seals Arctocephalus gazella in relation to oceanographic variables: a scale-dependent approach using geographic information systems. Mar Ecol Prog Ser 219:251-264

Higgins LV, Gass L (1993) Birth to weaning: parturition, duration of lactation. and attendance cycles of Australian sea lions Neophoca cinerea. Can J Zool 71:2047-2055

Higgins LV, Costa DP, Huntley AC, Le Boeuf BJ (1988) Behavioral and physiological measurements of maternal investment in the Steller sea lion, Eumetopias jubatus. Mar Mamm Sci 4:44-58

IMARPE (2002) Crucero 0202-03 de evaluación hidroacústica de recursos pelágicos tumbes a tacna. Instituto del Mar del Peru, Lima

Koen Alonso M, Crespo EA, García NA, Coscarella MA (2000) Food habits of the South American sea lion, Otaria flavescens, off Patagonia, Argentina. Fish Bull 98:250-263

Lea MA (2002) The foraging activity and provisioning strategies of Antarctic fur seals in relation to changes in oceanographic conditions at the Kerguelen Archipelago. PhD thesis, University of Tasmania, Hobart

Lea MA, Dubroca L (2003) Fine-scale linkages between the diving behavior of Antarctic fur seals and oceanographic features in the southern Indian Ocean. ICES J Mar Sci 60: 990-1002
Lea MA, Hindell MA, Guinet C, Goldsworthy SD (2002) Variability in the diving activity of Antarctic fur seals, Arctocephalus gazella, at Iles Kerguelen. Polar Biol 25:269-279

Limberger D, Trillmich F, Kooyman GL, Majluf P (1983) Reproductive failure of fur seals in Galapagos and Peru in 1982-83. Trop Ocean-Atmos Newsl October 1983:16-17

Lunn NJ, Boyd IL (1993) Effects of maternal age and condition on parturition and the perinata period of Antarctic fur seals. J Zool 229:55-67

Lunn NJ, Boyd IL, Barton T, Croxall JP (1993) Factors affecting the growth rate and mass at weaning of Antarctic fur seals at Bird Island, South Georgia. J Mamm 74:908-919

MacLennan D, Simmonds J (1992) Fisheries acoustics. Chapman \& Hall, London

McCann TS (1987) Female fur seal attendance behaviour. In: Croxall JP, Gentry RL (eds) Status, biology and ecology of fur seals. NOAA Tech Rep NMFS 51:199-200

McPhaden MJ (1999) Genesis and evolution of the 1997-98 El Niño. Science 283:950-954

Milette LL, Trites AW (2003) Maternal attendance patterns of lactating Steller sea lions (Eumetopias jubatus) from a stable and a declining population in Alaska. Can J Zool 81: $340-348$

Moron O (2002) Comparative analysis of warm events in the series 1970-2002 off the coast of Peru. Invest Mar 30: 98-99

Ñiquen M, Bouchon M (2002) Interactions between distribution and concentration of main pelagic resources in Peruvian waters during 1983-2001. Invest Mar 30:196-197

Ono KA, Boness DJ, Oftedal OT (1987) The effect of a natural environmental disturbance on maternal investment and pup behavior in the California sea lion. Behav Ecol Sociobiol 21:109-118

Paredes F, Elliot W (1997) Estudio biológico pesquero del 'camaroncito rojo' o 'munida' Pleuroncodes monodon frente a Pucusana, Lima. Inf Prog Inst Mar Peru 57:21-34

Pauly D, Tsukayama I (1987) The Peruvian anchoveta and its upwelling ecosystem: three decades of change. ICLARM Stud Rev 15

Pizarro L (1997) Crucero Oceanográfico BAP/Carrasco 9711-12 (27 noviembre-22 diciembre 1997), informe interno DOF. Instituto del Mar del Peru, Lima

Ryther JH (1969) Photosynthesis and fish production in the sea. Science 166:72-76

Sánchez G, Calienes R, Zuta S (2000) The 1997-98 Niño and its effects on the coastal marine ecosystem off Peru. Calif Coop Ocean Fish Invest Rep 41:62-86

Santojani H, Arneri E, Barry C, Belardinelli R, Cingolani N, Gianetti G, Kirkwood G (2003) Trends in anchovy (Engraulis encrasicolus, L.) biomass in the northern and central Adriatic Sea. Sci Mar 67:327-340

Soto KH (1999) Efectos de El Niño 1997-98 sobre el ciclo reproductivo del lobo marino chusco Otaria byronia en las islas Ballestas, Pisco, Perú. Tesis profesional, Universidad Nacional Agraria La Molina, Lima

Soto KH, Trites AW, Arias-Schreiber M (2004) The effects of prey availability on pup mortality and the timing of birth of South American sea lions (Otaria flavescens). J Zool Lond 264:419-428

Thompson D, Duck CD, McConnell BJ, Garrett J (1998) Foraging behaviour of lactating female southern sea lions (Otaria flavescens) in the Falkland Islands. J Zool Lond 246:135-146

Trillmich F (1986) Attendance behavior of Galapagos fur seals. In: Gentry RL, Kooyman GL (eds) Fur seals: maternal strategies on land and at sea. Princeton University Press, Princeton, NJ, p 168-185 
Trillmich F, Ono K (eds) (1991) Pinnipeds and El Niño: responses to environmental stress. Springer Verlag, New York

Trillmich F, Kooyman GL, Majluf P, Sanchez-Griñan M (1986) Attendance and diving behavior of South American fur seals during El Nino in 1983. In: Gentry RL, Kooyman GL (eds) Fur seals: maternal strategies on

Editorial responsibility: Howard I. Browman (Associate Editor-in-Chief), Storebø, Norway land and at sea. Princeton University Press, Princeton, NJ, p 153-167

Trillmich F, Ono KA, Costa DP, DeLong RL and 7 others (1991) The effects of El Niño on pinniped populations in the eastern Pacific. In: Trillmich F, Ono KA (eds) Pinnipeds and El Niño: responses to environmental stress. Springer Verlag, New York, p 247-260

Submitted: June 26, 2005; Accepted: October 13, 2005 Proofs received from author(s): March 8, 2006 